\title{
Secondary School Student's Perception towards Agriculture Subject in Public Secondary Schools in Nairobi County, Kenya
}

\author{
Kamau Titus Njoroge ${ }^{1}$ And John Aluko Orodho ${ }^{2 *}$ \\ ${ }^{I}$ Department of Educational Management, Policy and Curriculum Studies, School of Education, Kenyatta \\ University, Kenya. \\ ${ }^{2}$ Department of Educational Management, Policy and Curriculum Studies, School of Education, Kenyatta \\ University, Kenya and supervisor of Kamau Titus Njoroge ${ }^{I}$
}

\begin{abstract}
The study sought to examine the secondary school student's perception towards agriculture subject in public secondary schools in Nairobi County. The objectives of the study were: i)to examine the enrollment profile of students in Agriculture between 2009 and 2013,ii) find out students' perceptions regarding the availability of teaching resources and iii) determine students' perception regarding level of difficulty of Agriculture subject. The study was premised on the production Function Theory in education postulated by Psacharopoulos and Woodhall which refers to the process by which inputs are converted to outputs. The study adopted a descriptive survey research design using questionnaires as the main data collection instrument. Data was provided by 304 randomly students taking Agriculture subject in secondary schools in Nairobi County. The quantitative data was analyzed using descriptive statistics aided by the Statistical Package for Social Sciences (SPSS) computer programme version 20.The major findings were that although there was a declining enrollment trend, the enrolled students had positive attitude towards Agriculture subject. However, the teaching and learning of the subject was constrained by inadequate instructional resources, especially the tools, demonstration land and agricultural equipments. It was therefore recommended that the subject should remain an elective subject due to shortage of land and equipment, and the few students taking the subject should be motivated by receiving some of the farm produce and specialized training beyond the Kenya Institute of Curriculum Development syllabus to make the learners acquire modern agricultural techniques through internet and e-learning mode. [245 words].
\end{abstract}

Key words: perceptions towards agriculture, attitude, secondary schools, Nairobi County, Kenya.

\section{Introduction}

\section{Background Information}

Much research has been done in the field of students' attitudes towards certain subjects and their subsequent enrollment in those subjects and academic achievement (Orodho, 2014; Sherry, 2010). Many of these authors have given their suggestions about the factors that influence students within the school environment (Broughton, 2003; Sherry, 2010; Orodho, 2013, 2014; Republic of Kenya, 2012a, 2012b). Two of these factors include student attitudes and school context (Orodho, 2014). Research has shown that a large number of students' performances are affected by their attitudes towards specific subjects, education and academics in general (Bowen \& Richman, 2000; Richlin \& Cox, 2004). It has been suggested that when students demonstrate week commitment to their academics then they are bound to underperform. Additionally, some students with an unrealistic view of themselves may perform poorly too. For instance, those who tend to be overconfident or naïve about the requirements of their academics may register very poor performance (Broughton, 2003; Orodho, 2013; Republic of Kenya, 2010, 2011; Sherry, 2010).

Conversely, when students do not believe in themselves or when they have low self confidence, then chances are that they will underachieve. (Powers, 2006) Sometimes some students may think of themselves as people who cannot control their own destiny. They imagine that they are victims of the system and this can lead to academic failure. In other scenarios some students may be too proud to ask for help when they encounter a problem in their studies. (Bowen \& Richman, 2000; Orodho , 2013). Also, some students find it difficult to grow or develop because they tend to resist change and this impedes their academic progress. In other situations, a student may not work well in groups yet this is a necessary part of the academic environment (Orodho, 2014). Lastly, some students tend to avoid those areas where they perform poorly such as in science or mathematics. These and many more aspects of student's attitudes can be causes of academic failure (Orodho, 2014).

Writing on school-based factors, Orodho, Waweru, Ndichu and Nthinguri (2013) contend that school context is depicted through certain avenues. These avenues can either lead to excellent performance or poor performance depending on how they are implemented (Powers, 2006; Orodho, et.al. 2013) . In certain schools, the system may be too bureaucratic to the point that both teachers and students cannot do their jobs. This 
eventually leads to poor performance. (Bowen \& Richman, 2000) In other situations, teachers lack the skills to impart knowledge and this may cause failures. Likewise, some teachers may be disengaged with their students and this brings about problems in the end (Broughton, 2003; Okumbe, 1999). Additionally, there are certain school environments that are influenced by the external world to such a large extent that the students cannot concentrate on what they are meant to do. Such schools lack discipline, and effective management strategies employed by school managers, particularly the principals become extremely important (Okumbe, 1999; Orodho, 2014). Hence, to reiterate, a lot of research has been done in the field of academic achievement and many authors have given their suggestions about the factors that influence students within the school environment. Two of these factors include student attitudes and school context. Against this theoretical backdrop, it is necessary to look at how important these two factors are and exactly how those factors affect student outcomes. Thus, this study focused on secondary school student's perception towards agriculture subject in public secondary schools in Nairobi County, Kenya.

\section{Literature Review}

Globally, education today is widely recognized as the most effective development investment a country can make. According to World Bank (2007), it is one of the critical pathways to promote social and economic development. It is central to the development of a better life and better world. It raises economic development, reduces fertility rate, lowers infant and maternal mortality, improves the wellbeing of families, and ensures better prospects of education for children according to Gachukia (1999).

Bargetuny (1999) asserts that education promotes sound management of environmental resources such as water fuel, and is closely associated with the reduction of absolute poverty. He also argues that education increases participation in community and national affairs and in democratization of societies. Thus, education has an important influence on the quality of life. The development of human resource fundamentally depends on the level and intensity of formal and informal society but also for building human capabilities and opening up employment opportunities. Without education development can either be broad based or sustained (Orodho, 2014; Orodho, et.al.2013; Shery, 2010).

Secondary education in Kenya aims at achieving the national goals of education. Firstly, education in Kenya aims at promoting a sense of national unity among the diverse tribes, races and religions of Kenya (Republic of Kenya, 2008; 2012a,2012b). A sense of national unity will enable different people to live together in harmony, resulting in maximum contributions to the development of the country. Secondly, the purpose of education is also to produce citizens with appropriate knowledge, skills, and personal qualities that are necessary for economic growth. For the country to become industrialized and independent economically, it requires highly trained/skilled citizens (Republic of Kenya, 2007a, 2007b, 2008, 2010, 2012a, 2012b).

Thirdly, education provides opportunities for students to develop desirable attitudes and interpersonal relations that create the necessary social environment for the growth of the economy. Fourthly, education also aims at promoting social equality and a sense of social responsibility. In this regard, the education system attempts to provide equal learning opportunities for all. It also provides opportunities for competition for individual benefits and challenging opportunities for collective for development of individual student's talents, potential interests and abilities, characters, personality, moral, and religious beliefs (Orodho, et.al.2013).

According to the Ministry of Education (2003), teaching of agriculture in secondary schools should aim at ensuring that the learner is exposed to and taught the basic principles that are important of agricultural production in the country and exposing and involving learners in various practical and projects that will help them develop the necessary skills and abilities required in agricultural production. By the end of the agriculture courses, the student should be able to develop an interest and awareness of opportunity that exist in the agriculture sector, create an understanding of agriculture and its importance at the household and national level, and demonstrate that farming is a profitable and dignified occupation and develop and improve the knowledge and skills of basic agricultural practices. Other objectives are to provide a background for further studies in agriculture, develop self-reliance, resourcefulness, problem solving abilities and an occupational outlook on agriculture, promote good agriculture activities to enhance environmental conservation and good health, and take an active part in rural development by integrating agricultural activities in the curriculum(Republic of Kenya, 2007a, 2007b, 2008, 2010, 2012a, 2012b).

Zwanembegy (1972) asserts that since the establishment of formal schools in Kenya by European missionaries and colonial administrators in the early 1900s, there had been concern that education has not been sufficiently related to the practical needs of predominantly rural societies. Despite periodic efforts of introduce agriculture and vocational subjects into the schools, penal and community demand for academic education leading to high status and pay of the modern sector has kept most schools within an academic as a means of escape from agriculture and manual labour, schools remain oriented for the fortunate minority who gain access to the modern rather than to the vast majority who remain in traditional agriculture according to Morris (1976). 
After the achievement of independence in the 1960s, most African countries concentrated on rapid expansion of their educational systems. This expansion aimed at attaining self-sufficiency in high level manpower to Africanize the public service and later the private sector, as well as to respond to the overwhelming popular demand for more education. The pressures of quantitative expansion precluded major qualitative or structural reforms for most countries, but by the mid-1960s educators had again turned their attention to the problem of relating school systems to the needs of predominantly rural societies. Morris states that the Kericho Conference on Education, Employment and Rural Development linked the growing concern over unemployed school leavers, to rural development needs. This led to the introduction of agriculture as a subject in secondary schools in Kenya (Republic of Kenya, 1976; 2008).

Upon completion of this study the research may lay out clear causes of academic failure particularly in certain elective subjects like Agriculture, thus facilitating change in school environments. The research may assist teachers in formulating strategies to deal with attitudinal and contextual problems. Additionally, the research will transform traditional ways of thinking about education. It might remove stereotypical notions or ideas held by stakeholders in education. The research may also encourage greater investment in the psychological development of the student because it will review some of the pre-existing psychological attitudes that could be hindering academic excellence.

\section{Statement of the Problem}

Despite the fact that Agriculture is the backbone of Kenya's economy the teaching of agriculture in schools has not received as much emphasis as it should and only few students enroll for agriculture KCSE examinations nationally.

According to Economic Survey (2004), agriculture is the source of livelihood for more than a half of the world's population. Agriculture forms the backbone of most economies in sub-Saharan Africa. Agriculture remained the mainstay of the economy since independence in Kenya in 1963. History clearly indicates that the major economic activity in Kenya from the pre-colonial, colonial, up to the present is agriculture. This means agriculture is the backbone of Kenya's economy. Despite this, teaching of agriculture in schools has not received as much as it should and only few students seem to enroll for agriculture KCSE examination nationally.

\subsection{Purpose and objective of the study}

The purpose of this study was to investigate secondary school student's perception towards agriculture subject in public secondary schools in Nairobi County.

The objectives of the study were to:

i. Profile the enrollment trend in Agriculture from 2009 to 2013

ii. Examine the availability of learning resources in Agriculture.

iii. Determine perception of students regarding the level of difficulty of Agriculture as a subject in schools.

\section{Theoretical framework}

This study will adopt production Function Theory in education. According to Psacharopoulos and Woodhall (1985), the term production function refers to the process by which inputs are converted to outputs. The production function will be used to determine the maximum product which can be derived from a given combination of inputs. Students' perception of agriculture subject is a function of equipments availability, land availability (which is a special facility and a major factor of agriculture production), students' attitudes, teaching methodology, government policy and course content.

$\mathrm{P}=\mathrm{f}(\mathrm{E}, \mathrm{L}, \mathrm{A}, \mathrm{T}, \mathrm{G}, \mathrm{C})$

Where $\mathrm{P}$ - Perception

E - Equipments availability

$\mathrm{L}$ - Land availability

$\mathrm{T}$ - Teaching methodology

$\mathrm{G}-$ Government policy

C - Course content

The factors will form the basis of interrogating students' perception of agriculture subject is a function of the various factors in the equation, namely: equipments availability, land availability (which is a special facility and a major factor of agriculture production), students' attitudes, teaching methodology, government policy and course content. 


\section{Research Methodology}

The research involved a combination of techniques for data collection. Participants were students from a similar secondary school and were be analyzed under three parameters. Their cognitive and behavioral methods (attitudes) were addressed through questionnaires. Additionally, their perception about their school and their school environment were assessed through personal interviews. Lastly, their performance or levels of success were assessed by obtaining their academic reports. The latter procedure will focus on one subject i.e. Agriculture. The procedure was conducted among a sample size of 304 respondents who participated willingly. Permission was sought from the school administration and also from their respective parents.

After data collection, the researcher cross-examined the data to ascertain accuracy, completeness and uniformity. The data was analyzed and interpreted to provide meaningful and final results. Descriptive statistics were used to analyze the data. The researcher presented the data in frequency and percentage tables, bar graphs and pie charts to answer the research objectives and questions in relation to the research topic. The researcher applied the use of Statistical Package for Social Sciences (SPSS) computer software to analyze the data.

\section{Findings And Discussions}

\section{Trend in Students Enrollment Rate in Agriculture as percent of total KCSE candidature}

The first objective was to examine trend in students' enrollment rate in agriculture as percent of total KCSE candidature in selected years between 2009 and 2013. Table 1 shows the enrollment trend of students in Agriculture as a percentage of total national KCSE candidature between 2009 and 2013.

Table 1: National agriculture candidature trends as a percentage (\%) of the total KCSE candidate trends

\begin{tabular}{|l|l|l|l|}
\hline Year & Enrolment in Agriculture & Total KCSE Candidature & Percentage \\
\hline 2009 & 106,169 & 260,665 & 40.73 \\
2010 & 106,163 & 243,453 & 43.61 \\
2011 & 116,751 & 276,239 & 42.26 \\
2012 & 131,010 & 305,015 & 42.95 \\
2013 & 107,068 & 335,415 & 31.73 \\
\hline
\end{tabular}

The data carried in Table 1 indicates that although the total number of candidates enrolling for Agriculture has marginally increased from 106,169 in 2009 to 107,068 in 2013, the percentage has actually dropped from $40.73 \%$ to $31.73 \%$ over the period under review. The table shows that less than $50 \%$ of all the KCSE students have been choosing agriculture despite its great importance to the economy. Currently the government policy towards the agriculture is that it is an elective and not a compulsory subject. This policy is rather surprising given the importance of Agriculture to Kenya's economy.

\section{Students Perception Regarding Level of Adequacy of Instructional Resources}

This second objective of this study attempted to profile the perceptions of students enrolled in Agriculture with the aim of assessing factors that are likely to be responsible for students the low enrollment in the Agriculture subject. Table 2 exhibits data on students' level of satisfaction with the adequacy of garden tools.

Table 2 : Students level of satisfaction with the adequacy of Garden tools

\begin{tabular}{lll}
\hline Level of satisfaction & Frequency & $\%$ \\
\hline Strongly satisfied & 15 & 4.9 \\
Satisfied & 79 & 26.0 \\
Neutral & 79 & 26.0 \\
Dissatisfied & 38 & 12.5 \\
Strongly dissatisfied & 93 & 30.6 \\
\hline Total & 304 & 100.0 \\
\hline
\end{tabular}

Data carried in Table 2 shows that $93(30.6 \%)$ of the students are strongly dissatisfied and $38(12.5 \%)$ of them were dissatisfied that garden tools and equipments are adequate. This shows that a total of 131 students, constituting 43 percent of the total were dissatisfied with the level of availability and/or adequacy of agricultural tools. This indicates that the schools have inadequate garden tools and equipment necessary for agriculture practical, demonstrations and KCSE projects. This means that in most schools; garden tools and equipments were either inadequate or quite inadequate. Lack of such facilities was evident that it negatively affected perceptions of students towards agriculture subject.

Similarly, the respondents were requested to indicate the level of their satisfaction with the adequacy of livestock production tools and equipments for learning in their schools. Their responses are captured in table 3. 
Table 3: Student's level of satisfaction with adequacy of livestock production tools

\begin{tabular}{lll}
\hline Level of satisfaction & Frequency & $\%$ \\
\hline Strongly satisfied & 60 & 19.7 \\
Satisfied & 30 & 9.9 \\
Neutral & 62 & 20.4 \\
Dissatisfied & 90 & 29.4 \\
Strongly dissatisfied & 62 & 20.4 \\
\hline Total & 304 & 100.0 \\
\hline
\end{tabular}

The findings in table 3 indicate that 90 (29.6\%) respondents were dissatisfied and $62(20.4 \%)$ of them were strongly dissatisfied that livestock production tools and equipments are adequate. This shows that on the whole, 152 respondents, constituting $50 \%$ of the total indicated that livestock production tools were inadequate. This implied that the schools do not have adequate livestock production tools and equipment necessary tor practical and demonstrations. Therefore, in 14 out of the 20 schools; the livestock production tools and equipments were either inadequate or quite inadequate. Lack of such facilities was evident that it negatively affected perceptions of students towards agriculture subject.

The students were also asked to indicate their level of satisfaction with their schools' proper maintenance and regular acquisition of new tools and equipments. Table 4 presents the students' response on the issue.

Table 4 : Students level of satisfaction with proper maintenance of tools

\begin{tabular}{lll}
\hline Level of satisfaction & Frequency & $\%$ \\
\hline Strongly satisfied & 69 & 22.7 \\
Satisfied & 43 & 14.1 \\
Neutral & 30 & 9.9 \\
Dissatisfied & 40 & 13.2 \\
Strongly dissatisfied & 122 & 40.1 \\
\hline Total & 304 & 100.0 \\
\hline
\end{tabular}

Table 4 shows that $122(40.1 \%)$ of the students were dissatisfied and $40(13.2 \%)$ more were strongly dissatisfied that proper care, maintenance and acquisition of new tools and equipments is done well, promptly and regularly. This implied that there are no measures put in place by most schools to ensure proper care, maintenance and acquisition of new tools/equipment.

Finally, concerning agricultural learning materials and other related facilities, students were also asked to indicate their level of satisfaction with the adequacy of agricultural learning facilities, that is, agricultural rooms, stores and workshops in their schools. The findings are presented in Table 5.

Table 5: Students' level of satisfaction with adequacy of agricultural rooms and workshops

\begin{tabular}{lll}
\hline Level of satisfaction & Frequency & $\%$ \\
\hline Strongly satisfied & 72 & 23.7 \\
Satisfied & 68 & 22.4 \\
Neutral & 58 & 19.1 \\
Dissatisfied & 52 & 17.1 \\
Strongly dissatisfied & 54 & 17.8 \\
\hline Total & 304 & 100.0 \\
\hline
\end{tabular}

Findings on table 5 shows that $72(23.7 \%)$ and $68(22.4 \%)$ of the students were strongly satisfied and satisfied respectively that the number of agriculture rooms, stores and workshops in their schools are enough. This implies that most schools have ensured adequate rooms, store and workshops to improve performance in the subject. In turn, adequacy of tools and equipments was evident that it positively affected perceptions of students towards agriculture subject.

The study further aimed at establishing the effect of availability of land on students' perceptions of agriculture subject. The students were asked to indicate their level of satisfaction with agricultural land use in their respective schools. Firstly, they were requested to indicate their level of satisfaction with the amount of land set aside for use by form fours for their annual KCSE project work. The findings are presented in table 6 .

Table 6 : Students' level of satisfaction with land allocated for KCSE projects

\begin{tabular}{lll}
\hline Level of satisfaction & Frequency & $\%$ \\
\hline Strongly satisfied & 146 & 48.0 \\
Satisfied & 59 & 19.4 \\
Neutral & 52 & 17.1 \\
Dissatisfied & 17 & 5.6 \\
Strongly dissatisfied & 30 & 9.9 \\
\hline Total & 304 & 100.0 \\
\hline
\end{tabular}


Data carried in Table 6 reveal that $146(48 \%)$ of the respondents are strongly satisfied, $59(19.4 \%)$ are satisfied that land allocated for KCSE project work is adequate. This indicates that over two thirds of the respondents were satisfied with the land allocated for KCSE projects in their respective schools. This implies that schools have allocated adequate land for KCSE project work. This is a strong factor that could have possibly enhanced the students' perception towards agriculture subject.

Students were then asked to indicate their level of satisfaction with whether their schools' land use for agricultural production for the schools' domestic and commercial purposes was done maximally. The responses are carried in Table 7.

Table 7 : Students' level of satisfaction with schools' agricultural land use

\begin{tabular}{lll}
\hline Level of satisfaction & Frequency & $\%$ \\
\hline Strongly satisfied & 132 & 43.4 \\
Satisfied & 78 & 25.7 \\
Neutral & 38 & 12.5 \\
Dissatisfied & 28 & 9.2 \\
Strongly dissatisfied & 28 & 9.2 \\
\hline Total & 304 & 100.0 \\
\hline
\end{tabular}

Information contained in Table 7 indicate that $132(43.4 \%)$ of the students are strongly satisfied that school land is maximally used for agricultural production for school domestic use and commercial purposes, and $78(25.7 \%)$ more students are satisfied with the statement. Cumulatively, this indicates that over two thirds of the respondents had confidence in the agricultural practices and principles that are carried out in their schools. This factor most likely boosted their morale and positively influenced their perception towards agriculture subject.

\section{Level of Difficulty of Agriculture}

Finally, the students were asked to indicate their level of level of perception regarding whether agriculture subject was difficult to learn. Table 8 carries their responses.

Table 8: Students' perceptions regarding level of difficulty of Agriculture Subject

\begin{tabular}{lll}
\hline & Frequency & $\%$ \\
Level of satisfaction & & 11.5 \\
\hline Strongly satisfied & 35 & 2.3 \\
Satisfied & 7 & 6.9 \\
Neutral & 21 & 34.5 \\
Dissatisfied & 105 & 44.7 \\
Strongly dissatisfied & 136 & $\mathbf{1 0 0 . 0}$ \\
\hline Total & $\mathbf{3 0 4}$ & \\
\hline
\end{tabular}

Findings on table 8 show that 136 (44.7\%) students are strongly dissatisfied and $105(34.5 \%)$ of them are dissatisfied with the notion that agriculture is difficult to learn. The results indicate that nearly $80 \%$ of all the respondents concurred that Agriculture is not difficult to learn and post good results. This implies a positive attitude towards agriculture subject by the students taking it.

\section{Conclusions And Recommendations}

The research's major aim was to establishing a link between school contexts, student attitude and enrolment trend in Agriculture. This might enable teachers/ administrators/ stakeholders to look for ways of enhancing student enrolment in the subject. Based on the findings, it was concluded that:

i) Schools did not do proper acquisition of new tools and equipments and also did not maintain the existing ones properly. Lack of these essential learning materials negatively affected perceptions of students towards Agriculture.

ii) Most schools used land for agricultural purposes properly. This acted as their morale booster in positively influencing their perceptions towards agriculture subject.

iii) Agriculture subject is not difficult to learn. This implies a positive attitude towards agriculture subject by the students taking it.

iv) As per the current government policy, agriculture should remain an elective instead of being made a compulsory subject. Maintaining the current status quo seemed to be what influenced students' perceptions about agriculture subject positively.

v) The suggested practical work in the current agriculture subject syllabus is adequate. This implies that Agriculture syllabus can easily be covered under current time allocation within the secondary schools in Kenya. 
Based on the findings of this study, the researcher recommended that:

1) Schools should be provided with learning tools and equipments to facilitate learning of agriculture hence, improved students' perceptions towards the subject. The government and parents should assist in the provision of the required resources.

2) Most schools used land for agricultural purposes properly. This good trend should be maintained by the headteachers and agriculture teachers both for the good of the school and continued improvement of students' perceptions towards the agriculture. For schools with inadequate land for a school farm, the following may be done. Negotiating with a neighboring farmer to use or lease part of his/her land, attaching your school to another school or agricultural institution with a big piece of land, using boxes or pots to aid growing selected crops and starting projects which do not need a lot of space like rabbitry, poultry, and piggery.

3) Indicating agriculture subject is not difficult to learn, implied a positive attitude towards the subject by the students taking it. Therefore, the headteachers and agriculture teachers should maintain and improve the status quo by rewarding the students whenever they successfully concluded field production projects or excelled in agriculture examinations. Students may be given part of the yields or small tokens like exercise or text books.

4) Despite agriculture teachers having used a variety of teaching methods' they explore new methods like e-learning. This because most schools with computer laboratories are using them for computer lessons only. This can greatly improve students' perceptions about agriculture subject by its students positively, especially in schools where headteachers agree to be supportive.

5) v) The government through the MoE should uphold its current policy of retaining agriculture as an elective subject as long as students continued with their positive perceptions about it. Maintaining the current status quo seemed to be what influenced student's perceptions about agriculture subject positively. This is probably because students who choose agriculture do so because they already have underlying liking of the subject within them.

6) Government through the KIE should retain the current agriculture subject syllabus as long as students continued with their positive perceptions about it. Maintaining the current amount of suggested practical work in the current agriculture subject syllabus boosted their morale and thus positively influenced their perceptions towards the subject.

\section{References}

[1]. Bargetuny, MC (1999).Women's Education an Career Opportunities in Kenya. Nairobi: Nairobi Bowen, L. \& Richman, M. (2000): middle schools student's perceptions of the school environment. Journal of social work in education, 13, 22, 69-82

[2]. Broughton, A. (2003): The school success profile, Technology. Human services Journal, 21,

[3]. Powers, J. (2006): Assessing the functioning of schools as learning organizations .Journal for schools and children, 13, 29, 20 Creativity . Publishing Company.

[4]. Gachukia,E. (1999). Accelerating the Education of Girls and Women in Sub-Saharan Africa. Nairobi: FAW New Magazine 7(2) $5-11$.

[5]. Morris, S.R \& Sheffield.J.R. (1976).Agriculture in Secondary Schools, Case Studies of Botswana, Kenya and Tanzania. New York: The African American Institute.

[6]. Okumbe, J.A. (1998). Educational Management theory and practice. Nairobi: Nairobi Uni. Press Printing press.

[7]. Orodho, J. A. (2012). Techniques of writing Research Proposals and Reports in Education and Social Sciences. Nairobi: Kanezja Publishers.

[8]. Orodho, J. A. (2014).Policies on free primary and secondary education in East Africa: Are Kenya and Tanzania on course to attain Education For All (EFA) by 2015?.International Organization of Scientific Research (IOSR) Journal of Humanities and Social Sciences (IOR-JHSS).Vol.19, Issue1, Ver,V (Jan 2014) pp11-20 www.iosrjournals.org

[9]. Orodho, J. A. ,Waweru,P.N,.Ndichu,M \& Nthinguri, R. (2013).Basic education in Kenya: Focus on strategies applied to cope with school-based challenges inhibiting effective implementation of curriculum. International Journal of Education and Research. Vol.1.No.11 Novembeer20113. Pp1-20 www.ijer.com

[10]. Richlin,I,\& Cox, M.D.(2004).Developing scholarly teaching and the scholarship of teaching and learning through faculty learning communities. New Directions for Teaching and Learning 2004,127.

[11]. Republic of Kenya. (2007a). Kenya Vision 2030 Brochure. Nairobi: Government printers.

[12]. Republic of Kenya (2007b). Kenya vision 2030 course on line. Retrieved 10/02/12 from www. vision 2030on line.go.ke

[13]. Republic of Kenya (2008). Medium Term Plan 2008-2012. Nairobi: Government printers.

[14]. Republic of Kenya .(2009). Indicator handbook for the monitoring and evaluation of the Kenya vision 2030. Nairobi: Government printers.

[15]. Republic of Kenya (2010) Secondary School Sector as a Component towards the Realization of Kenya Vision 2030. Retrieved 10/06/12 from http://www.planning.go.ke 2010

[16]. Republic of Kenya (2011). First Medium Term Plan Update. Nairobi: Government printers.

[17]. Republic of Kenya (2012a). Kenya vision 2030: A Globally Competitive and Prosperous Kenya. Retrieved 10/05/12 from www. vision 2030.go.ke

[18]. Psacharopoulos, G. \& Woodhall, M. (1985). Education for Development: An Analysis of Investment Choices. New York: Oxford University Press.

[19]. Sherry,.R.(2010).Students attitudes and performance. http://www.goarticles.com/articles retrieved on March $31^{\text {st }} 2014$.

[20]. Zwanembegy, (2004).The Agricultural History of Kenya. Nairobi: East African Publishing House. 